------ Raf. J. Sci., Vol. 26, No.1, pp. 133-139, 2017------

\title{
Optimum Efficiency of CdS/ CdTe Thin Film Solar Cell
}

\author{
Nawfal Y. Jamil \\ Department of Physics / College of Science / University of Mosul
}

(Received 28/3/2014 ; Accepted 26/5/2014)

\begin{abstract}
In this study, the absorber layer (CdTe) and window layer (CdS) thickness parameters have been investigated through simulation by SCAPS to find out the higher conversion efficiency for the $\mathrm{CdS} / \mathrm{CdTe}$ thin film solar cell. It is found that the parameters $\mathrm{J}_{\mathrm{sc}}, \mathrm{V}_{\mathrm{oc}}, \eta$ are increased for the increasing absorber layer thickness, and quantum efficiency show overlapping after the $500 \mathrm{~nm}$ wavelength for different CdTe thicknesses. In addition, it is revealed that the highest calculated efficiency can be achieved with the absorber layer thickness of $3.5 \mu \mathrm{m}$ and window layer of thickness $0.05 \mu \mathrm{m}$, was $17.27 \%$. Where the effect of window layer show that the calculations gave, as CdS thickness increased $V_{\text {oc }}$, was nearly constant, but $J_{s c}, \eta$ decreased. Using best calculated thicknesses in this study for both CdS and CdTe, the fabricated CdS/ CdTe thin film solar cell efficiency measured $13.73 \%$, this is expected may be du to interface layer and density of stats on both films.
\end{abstract}

Keywords: Semiconductor, solar cell, thin film, SCAPS simulation.

\section{CdS/CdTe كماءة التحول المثل الخلية الثهسية الرقيقة}

\section{الملغص}

في هذه الدرلسة مُ بحث تأثير تغييرسمك الطقة الماصة (CdTe) والطقة النفذة (CdS) من خلل محلكة حلسوبية

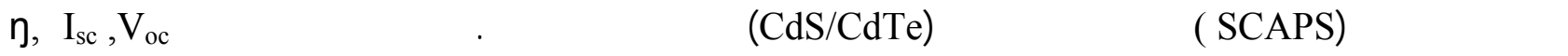
تزدادمع زيادةسمك الطقة الماصة بحيث ان اعلى كفاءة معسوبة كافت عندسمك الطقة الماصة

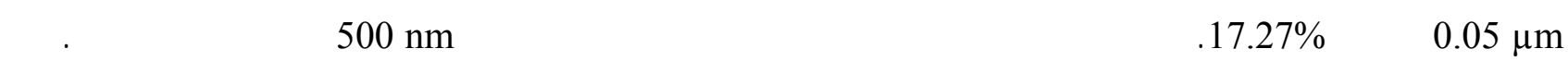

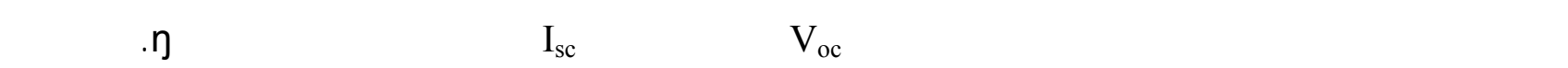
خليةشطسية لأفضلسمك الطقة الماصة والنافة ومن القيلست كالت كفاءة الخلية المصنعة هي

الكاملت الدالة: لشباd ألموصلات، خلاياشطسية، اغشية رقيقة، محلكة حلسوبية.

\section{INTRODUCTION}

During the last Decade the hetrojuncfion $\mathrm{CdS} / \mathrm{CdTe}$ have been investigated intensively (Bonnet and Meyers, 1998), (Romeo et al., 2003), (Mathew et al., 2004), (Gessert et al., 1996), (Tiwari et al., 2004), (Compaan et al., 1999), as a part of II-VI material (Mahmood et al., 2012) and (Dawad et al., 2013) due to calculated upper limit of CdTe solar cell efficiency because of its band gap close $26 \%$. Where CdS/CdTe thin film solar cell with efficiency $8 \%$ fabricated on an industrial scale for several years, in same time a lot of works has been done in order to increase CdS/CdTe solar cell efficiency. Later few years the efficiency of CdTe based solar cell devices has raised to $16.5 \%$ due to employment technique including post heat treatment in the presence of $\mathrm{CdCl}_{2}$ (Wu et al., 2001), (Romeo et al., 2004) and (Jahn et al., 2001). Where commercial CdTe module efficiency of $>10 \%$ have been achieved (Cooke, 2008). Still demands on the best thickness of 
CdTe as absorber (Salave et al., 2013) and CdS as window layer wanted. This type of solar cell have an advantage of the variety technique of fabrication (Pérez-Hernánde et al., 2013) among of them magnetron sputtering (Gupta and Compaan, 2004), (Gupta and Compaan, 2005), (Gupta et al., 2006) which gives big chance of producing dense and homogenous layers at low substrate temperature (Hur et al., 2008), and also it is good device performance (Hadrich et al., 2009), (Luschitz et al., 2009) with thin layers (Jaegermann et al., 2009).

In this work a simulation using (SCAPS) (This group of programs includes AMPS-ID, SCAPS-ID, PC-ID, ASA, and AFORS-HET (Burgelman et al., 2004). Among these programs is SCAPS-ID that used in this work, (Burgelman et al., 2000) on CdS/CdTe thin film solar cell have been used to calculate the extreme values of absorber and window layer of $\mathrm{CdS} / \mathrm{CdTe}$ thin film solar cell by fixing one of them and varying the other and finding out the best calculated efficiency. Then choosing the thickness of absorber and window layer for CdS and CdTe For fabricating $\mathrm{CdS} / \mathrm{CdTe}$ thin film solar cell (using magnetron sputtering technique) and from J-V characteristics experimental efficiency value calculateds and comparing between the calculated and experimentally measured efficiency have been done. To find out the effect of thickness variation of CdS/CdTe hetrojunction, the physical model in reference (Burgelman et al., 2000) dependent with respecting that high quality ohmic back contact and presence of charged interface states.

\section{THEORETICAL DESIGN}

The DC electrical characteristics of thin film heterojunction solar cells (CdS/CdTe) can be investigated with SCAPS ID. In this work SCAPS- program used to study the effect of absorber layer thickness for CdTe thin films solar cells on the solar cell parameters demonstrated, like open circuit voltage (Voc), short circuit current density (Jsc), conversion efficiency ( $\eta$ ) and the quantum efficiency (QE). The best electrical performance for $\mathrm{CdS}$ and CdTe solar cells can also be simulated. SCAPS is used to imitate and investigate all the available research-level of $\mathrm{CdTe} / \mathrm{CdS}$ solar cells with various window layers. In the simulation, $n-C d S$ and p-type CdTe layer parameters are emphasized to investigate the benefits of using CdS as window layer in CdTe solar cells and comparative study with $\mathrm{CdTe} / \mathrm{CdS}$ structure. By incorporating the various material parameters into SCAPS for all of the analysis aspects, changes in the values for efficiency, open circuit voltage, short circuit current, fill factor and the quantum efficiency $(\mathrm{QE})$.

\section{Experimental procedure for fabricating CdS/CdTe solar cell:}

The preparation process is included by depositing Al layer (back contact) on glass substrate and followed by depositing p-type CdTe layer on the substrate with magnetron sputtering method (SQM-242, sigma instrument S4160 Hitachi, Japan. Department of physics and nanotechnology, Sumy state university technical, Sumy, Ukraine), the window layer is also deposited on the CdTe solar cell with thickness $(0.05 \mu \mathrm{m})$ using sputtering magnetron method. A figure net of gold to collect the photocurrent also deposited by sputtering method. Schematic structure of the solar cell given as follow:

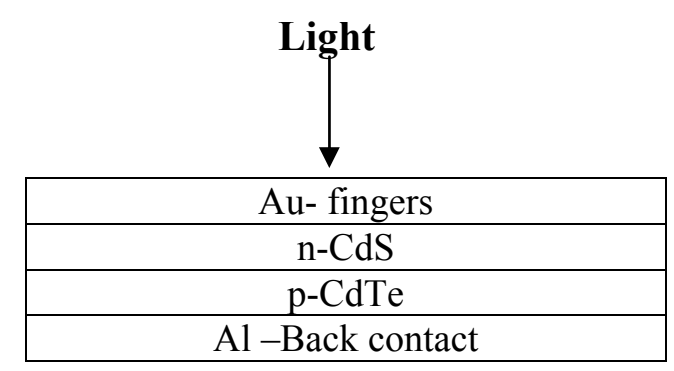

Fig. 1: Schematic diagram for CdS/CdTe thin film solar cell

Electrical measurement has done of the sample at illumination with $100 \mathrm{mw} / \mathrm{cm}^{2}$ on input power using lamp of 100 watt. 


\section{RESULTS AND DISCUSSIONS}

\section{Theoretical calculations by SCAPS simulation program:}

Solar cell as shown in Fig.(1) of CdS/CdTe designed and SCAPS program used for simulation of the expected characteristics, efficiency and QE values, with varying CdS thickness.

Fig. (2) shows the simulated J-V solar cell characteristics for CdTe with constant thickness $(3 \mu \mathrm{m})$ and varying $\mathrm{CdS}(0.05-2.5 \mu \mathrm{m})$ thin film thickness through SCAPS program. The simulated values of $\mathrm{J}_{\mathrm{sc}}, \mathrm{V}_{\mathrm{oc}}, \mathrm{FF}$ and efficiency as corresponding solar cell output parameters are recorded in Table1. Which show a decrease in the short circuit current with increase of CdS thickness and finally a decrease in the efficiency and that is expected because the solar cell window should be very thin compared to the absorber.

Current Density

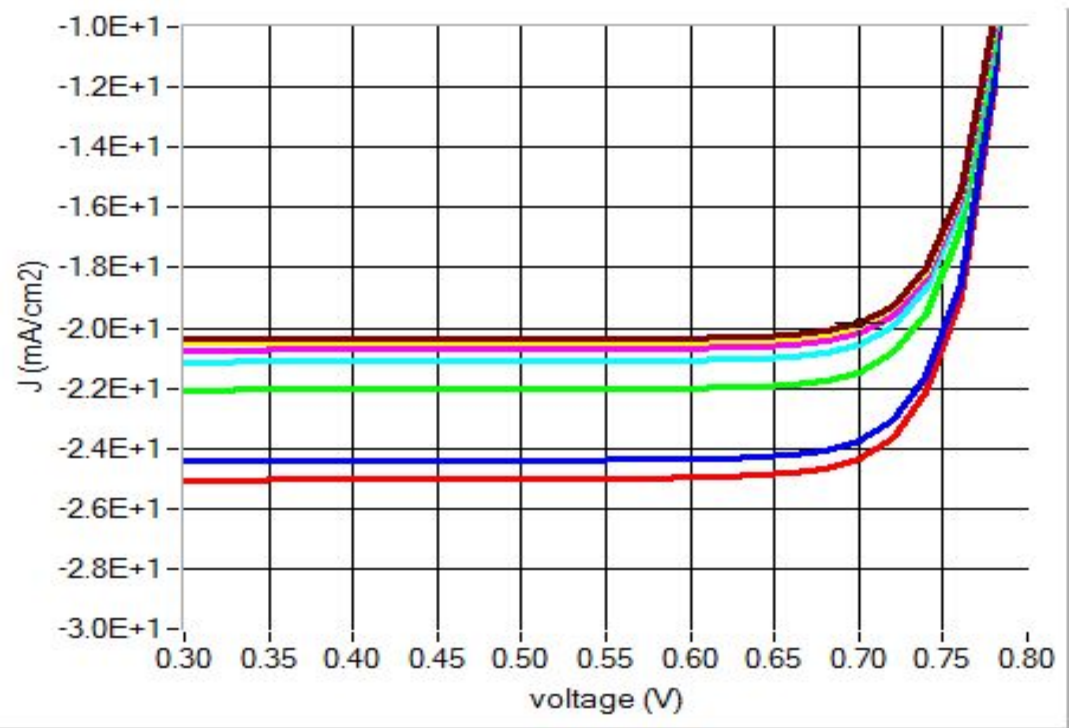

Fig. 2: J.V spectra for different CdS thickness $(\operatorname{Red}=0.05 \mu \mathrm{m}$, brown $=2.5 \mu \mathrm{m}) \mathrm{CdTe}=3 \mu \mathrm{m}$

Table 1: Solar cell parameters using SCAPS program with thickness of CdTe $(3 \mu \mathrm{m})$ and variant CdS thickness

\begin{tabular}{|l|l|l|l|l|l|}
\hline № & CdS/Thickness/ $\boldsymbol{u m}$ & $\boldsymbol{V}_{\boldsymbol{o c}}, \boldsymbol{V}$ & $\boldsymbol{J}_{\boldsymbol{s c}}, \mathbf{m A} / \mathbf{c m} 2$ & $\boldsymbol{F F}, \mathbf{\%}$ & $\eta, \%$ \\
\hline 1 & $\mathbf{0 . 0 5}$ & 0.798 & 25.11 & 85.55 & $\mathbf{1 7 . 1}$ \\
\hline 2 & $\mathbf{0 . 1}$ & 0.797 & 24.50 & 85.53 & $\mathbf{1 6 . 6}$ \\
\hline 3 & $\mathbf{0 . 5}$ & 0.796 & 22.10 & 85.50 & $\mathbf{1 5 . 0}$ \\
\hline 4 & $\mathbf{1}$ & 0.796 & 21.15 & 85.48 & $\mathbf{1 4 . 4}$ \\
\hline 5 & $\mathbf{1 . 5}$ & 0.795 & 20.77 & 85.46 & $\mathbf{1 4 . 1}$ \\
\hline 6 & $\mathbf{2}$ & 0.794 & 20.55 & 85.45 & $\mathbf{1 4 . 0}$ \\
\hline 7 & $\mathbf{2 . 5}$ & 0.794 & 20.44 & 85.45 & $\mathbf{1 3 . 9}$ \\
\hline
\end{tabular}

Fig. (2) and Table1. Show that the efficiency decreased as CdS thickness increase. The optimum conversion efficiency is about $17.1 \%$ at $0.050 \mu \mathrm{m} \mathrm{CdS}$ thickness.

Fig. (3) shows the simulated quantum efficiency (QE) spectra for different CdS thickness 
which shows that at lowest $(0.05 \mu \mathrm{m})$ thickness of CdS more photons transmutes, which improves the overall efficiency of the theoretical design of solar cell.

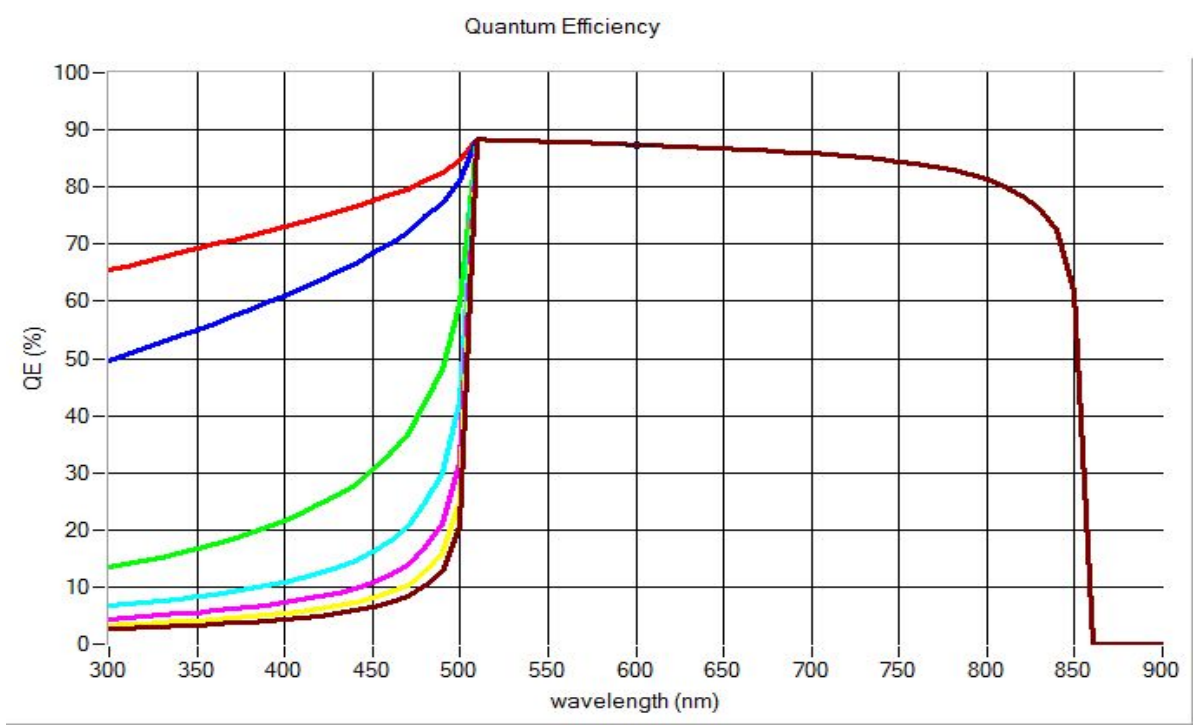

Fig. 3: Simulated QE spectra for different CdS thickness $(\operatorname{Red}=0.05 \mu \mathrm{m}$, brown $=2.5$ $\mu \mathrm{m}) \mathrm{CdTe}=3 \mu \mathrm{m}$

Fig. (4) shows the simulated J-V solar cell characteristics for CdTe with varied thickness and constant CdS thin film thickness $(0.05 \mu \mathrm{m})$ through SCAPS program. The simulated values of $\mathrm{J}_{\mathrm{sc}}$, $\mathrm{V}_{\mathrm{oc}}, \mathrm{FF}$ and efficiency as corresponding solar cell output parameters are recorded in Table2, which show an increase in the short circuit current and slow increase in the open circuit voltage with increase of CdTe thickness and finally an increase in the our goal the efficiency and that is expected because the absorber should be thicker as compared to the window of the solar sell. In Fig. (4) and (Table 2) Show efficiency increasing as CdTe thickness increased. The optimum conversion efficiency is about $17.27 \%$ at $3.5 \mu \mathrm{m}$ CdTe thickness.

\section{Current Density}

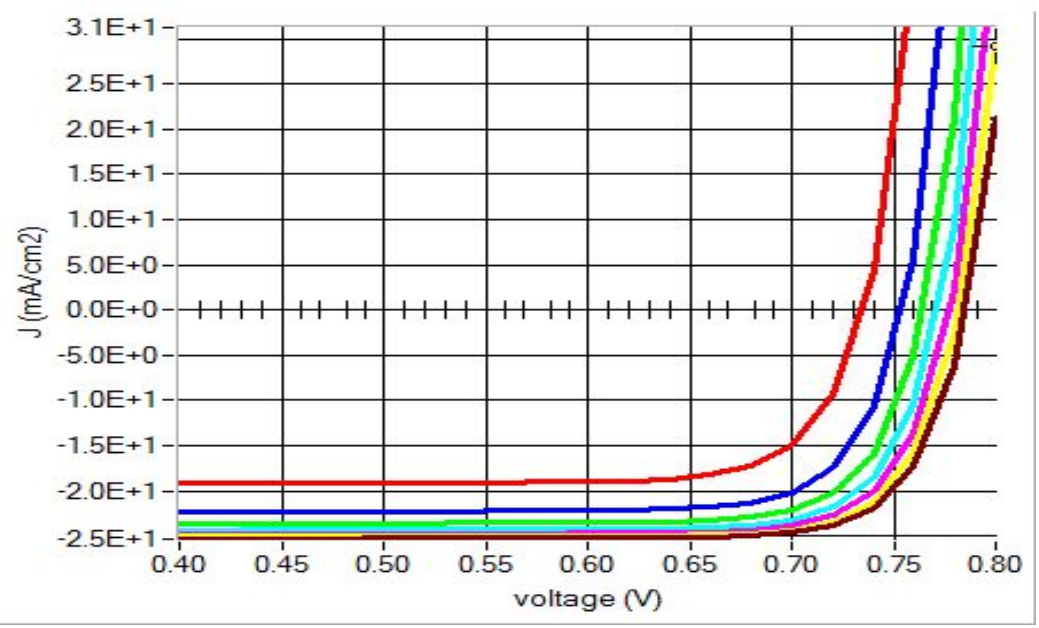

Fig. 4: J.V spectra for different CdTe thickness $(\operatorname{Red}=0.5 \mu \mathrm{m}$, brown $=3.5 \mu \mathrm{m}) \mathrm{CdS}$ thickness $=0.05 \mu \mathrm{m}$ 
Table 2: Simulated solar cell parameters with thickness of $\mathrm{CdS}(0.05 \mu \mathrm{m})$ and variable CdTe thickness

\begin{tabular}{|l|l|l|l|l|l|}
\hline № & $\begin{array}{l}\text { CdTe/Thickness/ } \\
\mu \mathrm{m}\end{array}$ & $V_{o c}, V$ & $J_{s c}, \mathrm{MA} / \mathrm{cm} 2$ & $F F, \%$ & $\boldsymbol{\eta}, \boldsymbol{\%}$ \\
\hline 1 & $\mathbf{0 . 5}$ & 0.734 & 19.51 & 83.98 & $\mathbf{1 2 . 0 4}$ \\
\hline 2 & $\mathbf{1 . 0}$ & 0.754 & 22.50 & 85.47 & $\mathbf{1 4 . 5 1}$ \\
\hline 3 & $\mathbf{1 . 5}$ & 0.764 & 23.73 & 86.02 & $\mathbf{1 5 . 6 2}$ \\
\hline 4 & $\mathbf{2}$ & 0.772 & 24.40 & 86.36 & $\mathbf{1 6 . 2 7}$ \\
\hline 5 & $\mathbf{2 . 5}$ & 0.777 & 24.81 & 86.52 & $\mathbf{1 6 . 7 0}$ \\
\hline 6 & $\mathbf{3}$ & 0.782 & 25.10 & 86.65 & $\mathbf{1 7 . 0 1}$ \\
\hline 7 & $\mathbf{3 . 5}$ & 0.785 & 25.31 & 86.80 & $\mathbf{1 7 . 2 7}$ \\
\hline
\end{tabular}

Fig. (5) shows the simulated quantum efficiency (QE) spectra for different CdTe thickness which shows that at thickness $3.5 \mu \mathrm{m}$ more photons absorbed, which improves the overall efficiency of theoretical design solar cell.

Quantum Efficiency

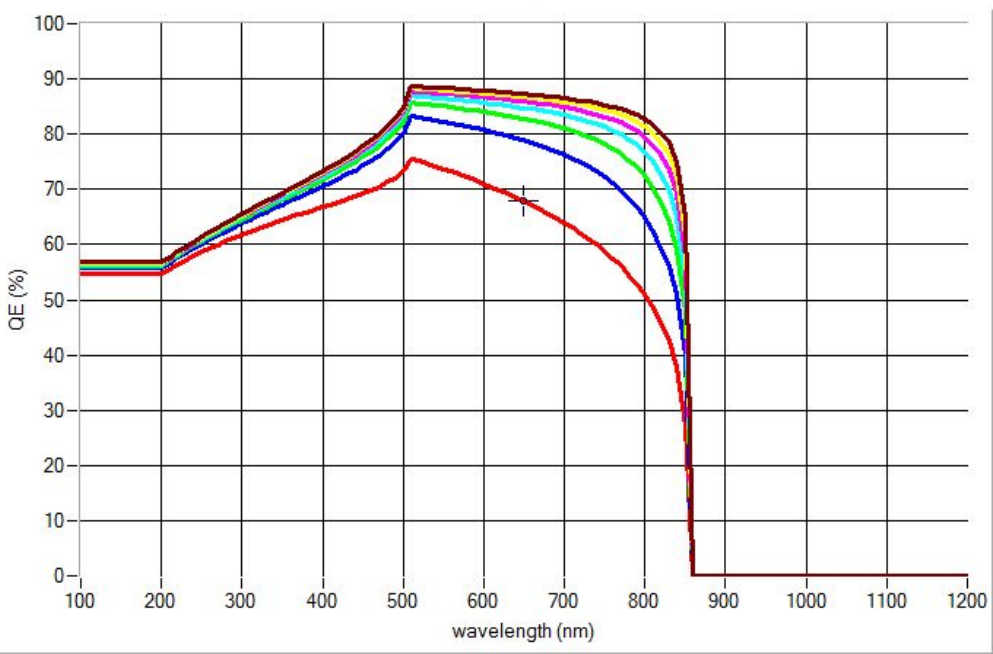

Fig. 5: Simulated QE spectra for different CdTe thickness $(\operatorname{Red}=0.5 \mu \mathrm{m}$, brown $=3.5$ $\mu \mathrm{m}) \mathrm{CdS}$ thickness $=0.05 \mu \mathrm{m}$

It is clear from Fig. (4) and (Table 2) that values of $V_{o c}, J_{s c}$ of the solar cell parameters increased as CdTe thickness increased. The conversion efficiency increased until the thickness reached at around $3.5 \mu \mathrm{m}$. Further increase in the thickness of the films does not show any improvement in the efficiency. The optimum conversion efficiency is nearly $7.27 \%$ observed. Also it is appear that the efficiency increases as the thickness increase and saturates after $500 \mathrm{~nm}$ which is shown in Fig. (4).

\section{Experimental Calculation for fabricated solar cell:}

As explained before the $\mathrm{CdS} / \mathrm{CdTe}$ thin film solar cell fabricated with $\mathrm{CdS}$ thickness $0.05 \mu \mathrm{m}$ and CdTe thickness $3.5 \mu \mathrm{m}$. From experimental measurements $\mathrm{J}_{\mathrm{sc}}, \mathrm{V}_{\mathrm{oc}}$, the FF, and efficiency were calculated .

Comparing simulated results with the practical results for prepared solar cell $\mathrm{n}$-CdS $(0.05$ $\mu \mathrm{m} / \mathrm{CdTe}(3.5 \mu \mathrm{m})$ as shown in Table (3) it is clear that the practical efficiency is smaller than simulated with same thicknesses by $20 \%$ which practically acceptable in addition to the surface density states of both material $(\mathrm{CdTe}, \mathrm{CdS})$ also the interface layer between two material. 
Table 3: Output of practical fabricated n-CdS/p-CdTe solar cell

\begin{tabular}{|l|l|l|l|}
\hline$V_{\boldsymbol{o c}}, \boldsymbol{V}$ & $\boldsymbol{J}_{\boldsymbol{s c}}, \mathbf{\mathrm { mA }} / \mathbf{c m} 2$ & $\boldsymbol{F F}, \boldsymbol{\%}$ & $\eta, \%$ \\
\hline 0.7850 & 20.525 & 85.20 & $\mathbf{1 3 . 7 3}$ \\
\hline
\end{tabular}

The conversion efficiency ( $\eta \%)$ of solar cell is calculated from the relation.

$$
\eta=\left[\frac{I_{s c} V_{o c} F F}{P_{h v}}\right] \times 100 \%
$$

Where $P_{h v}$ is the power density of the incident radiation. The fill factor (FF) which is a measure of the ideality of the system, is calculated from the relation:

$$
F F=\left[\frac{I_{m} V_{m}}{I_{s c} V_{o c}}\right] \times 100 \%
$$

Where $I_{m}$ and $V_{m}$ are respectively the current and voltage obtained at maximum power point on the photovoltaic power output curve. The fill factor values are in agreement with theoretically calculated.

\section{CONCLUSION}

From this numerical analysis of heterojunction- solar cells with $\mathrm{CdTe}$ and $\mathrm{CdS}$ window layers, electrical performances for the $\mathrm{CdS} / \mathrm{CdTe}$ solar cells have been investigated in terms of absorber layer thickness and window. The increasing of CdTe absorber layer thickness results in higher Jsc, Voc and $\eta$ better performance. Where window layer showed as it is very thin it gives best performance. Where the fabricated solar cell device gave lower efficiency about $20 \%$.

\section{REFERENCES}

Bonnet, D.; Meyers, P.V.; Mater, J.R. (1998). Cadimuim Telluride for thin film solar cell. 13, 2740. Burgelman, M.; Nollet P.J.; Degrave, S. (2000). Modelling polycrystalline semiconductor solar cells. Thin solid films. 361,527-532.

Burgelman, M.; Verschaegen, J.; Degrave, S.; Nellet, P. (2004). "Modelling Thin Film PV Devices". Progress in photovoltaic: Research and application; John Wiley and sons.

Compaan, A.D.; Sites, J.R.; Birkmire, R.W.; Ferekides, C.S.; Fahrenbruch, A.L. (1999). Critical issues and research needs for CdTebased splar cell. Electrochem. Soc. Proc., 241, 99.

Cooke, M. (2008). Semiconductor today compounds and advanced silicon. 3, 74.

Dawad, Z.A.; Najim, L.A.; Jamil, N.Y. (2013). The study of the effect of gamma ray and neutrons on thr physical properties of Zinc Oxide thin film. Raf. S. J., 24(4A), 88-98.

Gessert, T.,; Mason, A.; Sheldon, P.; Swartzlander, A.; Niles, D.; Coutts, T. (1996). Development of $\mathrm{Cu}$-doped $\mathrm{ZnTe}$ as a back contact interface layer for thin film $\mathrm{CdS} / \mathrm{CdTe}$ solar cell. $J$. Vac.Sci. Technol. A 14(3), 806.

Gupta, A.; Compaan, A.D. (2004). All-sputtered 14\% CdS/CdTe thin film solar cellwith $\mathrm{ZnO}: \mathrm{Al}$ transparent conducting oxide. Appl. Phys. Lett. 85, 684.

Gupta, A.; Compaan, A.D. (2005). High efficiency , 0.8 micron CdS/CdTe solar cell. Mater. Res. Soc. Symp. Proc. 865, F14, 33.

Gupta, A.; Parikh, V.; Compaan, A.D. (2006). High efficiency ultra- thin film sputtered CdTe solar cell. Sol. Energy Mater. Sol. Cells. 90, 2263. 
Hadrich, M.; Kraft, C.; Metzner, H.; Reislohner, U.; Loffler, C.; Witthuhn, W. (2009). Formation of $\mathrm{CdS}_{\mathrm{x}} \mathrm{Te}_{1-\mathrm{x}}$ at the p-n junction of CdS-CdTe solar cells. Phy. Status Solidi, C 6/5, 12571260.

Hur, S.G.; Kim, E.T.; Lee, J.H.; Kim, G.H.; Yoona, S.G. (2008). Characterization of photoconductive cdS thin films prepared on glass substrate for photoconductive senser applications. J. Vac. Sci. Technol. B 26, 1334-1337.

Jaegermann, W.; Klein, A.; Mayer, T. (2009). Interface engineering of energanic thin film solar cell-material- science challenges for advanced physical concepts. Adv. Mater. 21, 4196-4206.

Jahn,U.; Okamoto, T.; Yamada, A. (2001). Doping and intermixing in CdS/CdTe thin filmsolar cell. Appl. Phys. 90, 2553.

Luschitz, J.; Siepchen, B.; Schaffner, J.; Lakus-Wollny, K.; Haindl, G.; Klein, A.; aegermann, W. (2009). CdTe thin film solar cells : interrelation of nucleation, structure, and performance. Thin Solid Films, 517, 2125-2131.

Mahmood, M.T.; Jamil, N.Y.; Mostafa, N. A. (2012). The optical and electrical properties of Cdse thin films prepared by CBD technique. Raf. Sci. J., 23(1), 116-125.

Mathew, X.; Enriquez, J.P.; Romeo, A.; Tiwari, A.N. (2004). CdTe/CdS solar cell on flexible substrate. Sol. Energy, 77.

Pérez-Hernández, G., Pantoja-Enríquez, J.; Escobar-Morales, B.; Martinez-Hernández, D.; DíazFlores, L.L.; Ricardez-Jiménez, C. Mathews, N.R.; Mathew, X. (2013). Comparative study of CdS thin films depositing by different techniques. Thin Solid Film, 535, 154-157

Romeo, A.; Arnold, D.; Bätzner, D.L.; Zogg, H.; Tiwari, A. (2002-2003). Development of high efficiency flexible CdTe solar cell. Proceedings of the Conference "PV in Europe from PV Technology to Energy Solutions"; Rome; Italy, October 7-11, 154.

Romeo, N.; Bosio, A.; Canevari, V.; Podestà, A. (2004). Recent progress on CdS/CdTe thin film solar cell. Sol. Energy, 77, 795

Salavei, A.; Rimmaudo, I.; Piccinelli, F.; Romeo A. (2013). Influence of CdTe thickness on the structural and electrical properties of CdTe/CdS solar cell. Thin Solid Film, 535, 257-260.

Tiwari, A.N.; Khrypunov, G.; Kurdzesau, F.; Bätzner, D.L.; Romeo, A. (2004). CdTe solar cell in novel configuration. Progress in Photovoltaics: Research and Applications, 12, 33.

Wu, X.; Keane, J.C.; Dhere, R.G.; DeHart,C.; Albin, D.S.; Duda, A.; Gessert, T.A.; Asher, S.; Levi, D.H.; Sheldon, P. (2001). 16.5\% efficeint CdS/CdTe polycrystalline thin film solar cells. Proceedings of the 17th European Photov. Solar Energy Conf., Munich, Germany, p. 995: II. 